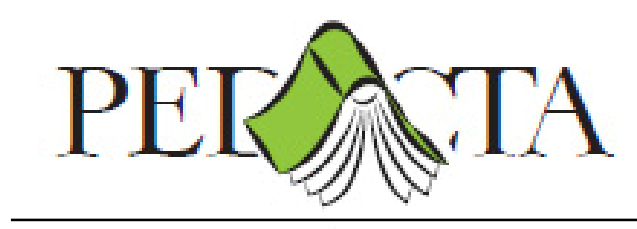

\title{
TANULÁSI TECHNIKÁK A PEDAGÓGUSI MUNKÁBAN A ROMÁNIAI ÉS NEMZETKÖZI GYAKORLATBAN
}

\author{
LEARNING TECHNIQUES IN TEACHERS \\ PEDAGOGICAL WORK, IN THE ROMANIAN AND \\ INTERNATIONAL PRACTICE
}

\author{
Bardocz Orsolya, Barabási Tünde
}

\begin{abstract}
In this paper, we persume that an educational system's efficiency is closely related to the fact of how many learning techniques contains the educational system's curriculum. We reviewed Romania's core curriculum and discipline programs as well as the curricula and syllabuses of countries that achieved good results at international testing (PISA), as Estonia and Sweeden. During the reviewing, the main aspect of document analysis was to find and collect the recommended learning techniques. We found that there is no relation between educational system's efficiency and how many learning techniques contains its currciculum; we didn't find more techniques in the Estonian and Sweedish curriculum, as in the Romanian. In the base of our research, it seems that other fact or facts influences the effectiveness of and educational system, less the number of the recommended learning techniques.
\end{abstract}

Keywords: learning techniques, international surveys, curriculum, education system's efficiency, Romania, Estonia, Sweeden

\section{Bevezetés}

Szülőben és pedagógusban gyakran felmerül a kérdés, hogy miként tudjuk gyerekeinket megtanítani hatékonyan tanulni? Mi kell ahhoz, hogy egyszerüen, de mégis hatékonyan tanuljanak úgy, hogy tevékenységük során az élethosszig tartó tanulás igénye is kialakuljon, és képesek is legyenek e tevékenység hatékony megvalósítására? Bizonyos, hogy mind az oktatási rendszer eredményessége, mind az oktatást szabályzó dokumentumok, illetve a pedagógusok is hozzájárulnak a gyerekek eredményes tanulási folyamatának, illetve az élethosszig tartó tanulás igényének kialakításához. Mindezt annál is fontosabbnak ítéljük, minthogy az iskolai nevelési-oktatási tevékenység a kulcskompetenciák megalapozásának és fejlesztésének rendelődik alá, és így kérdés, hogy a tanulási kulcskomptencia alakításának fókusza milyen mértékben érvényesül a tantervi tevékenységi, illetve módszertani ajánlások szintjén.

Kutatásunk szükségességének elvégzését a fenti kérdések, valamint a 2016. december 6.-án közölt 2015ös PISA felmérés (PISA 2015, 2016), és a 2012 decemberében közzé tett szintén 2011-es TIMSS eredmények (TIMSS 2011, 2012) is megerősítették. Ha áttekintjük az eredményeket láthatjuk, hogy az európai nemzeteket tekintve, az északi országok kimagaslóan teljesítenek (Finnország, Észtország, Svédország). Úgy véljük, hogy eredményességük oka, nem csak az oktatási rendszerük fejlettségében rejlik, hanem ebből következően abban is, hogy az oktatást szabályzó dokumentumok a tanulásról olyan 
személeletet és attitüdöt közvetítenek a pedagógus - a pedagógusokon keresztül pedig a tanulók - felé, mely az élethosszig tartó tanulás tevékenységét segíti, számos tanulási technika alkalmazásának tantervi ajánlása által is, aminek következtében várható, hogy a gyakorló pedagógusok változatos módszertárat használva fel is vértezik a tanulókat ezek önálló alkalmazására is. A tantervek és a tantárgyi programok, minden bizonnyal olyan tanulási technikákat sorakoztatnak fel, amelyek éppen a hatékony tanulást támogatják. Mivel úgy véljük, hogy az elemi oktatás szerepe igen erőteljes a „megtanulni tanulni” vonatkozásában, a tanítóknak a tanulási technikák, módszerek tárházának gazdagítása és az alkalmazás lehetőségeinek megvilágítása ugyanúgy prioritás kell, hogy legyen, mint a tanulási tevékenység iránti pozitív attitüd alakítása. Ezen a szemléletünknek alárendelten kutatásunkban az elemi oktatás terveinek vizsgálatára fókuszáltunk.

\section{Tanterv, tanítás és eredményesség}

Míg az iskolai értelemben vett tanulás az oktatási folyamatra vetítve a tanuló tevékenysége, addig a tanítás a pedagógus tevékenységét jelöli (ez természetesen nem azt jelenti, hogy a gyerek nem taníthat és a pedagógus nem tanulhat). A tanítás vagy oktatás, az oktatási folyamatban megvalósuló tevékenység, mely az oktatási rendszer szerves részét képezi.

Barabási (2007, 97; Szivák, 1996) a következőképpen határozza meg az oktatási rendszer fogalmát: ,az oktatási intézmények hálózatának, illetve az oktatás irányításának egybeszerveződése". Az oktatási rendszer alapját az iskola, - melyet hasonlóan rendszerként kell tekintenünk, már csak azért is, mert jól meghatározott terv alapján múködik - valamint az oktatást szabályzó dokumentum képezi. Ezt tantervnek nevezzük. Elöírja az egységesen tanítandó tartalmakat (korszerü értelemzésben!), melyeket különböző tantárgyakba, diszciplínákba szervez. Két meghatározó funkciót tölt be: oktatáspolitikai- és pedagógiai funkciót. Az oktatáspolitikai funkcióját tekintve, hivatalos dokumentum, az oktatásirányítás eszköze, mely közvetíti a társadalom által elvárt értékeket (mint például az empátia képességének fontosságát, vagy a tisztelettudatosságot) és a nevelési eszményt is. Emellett, közli az oktatás rövid- és hosszú távú céljait is: rövid távú célnak tekintendő például a számok leírásának képessége, míg hosszú távú célként a bonyolult egyenletek elvégzését nevezhetjük meg. Pedagógiai funkcióját tekintve a tanítási-tanulási folyamat hosszú távú tervezésének dokumentuma, hiszen koragyermekkortól kezdődően egészen a fiatal felnőttkorig meghatározza és előírja az elsajátítandó tartalmakat (a tantárgyi programokon keresztül), a megtanulandó és fejlesztendő képességeket, készségeket, kompetenciákat ${ }^{1}$. A tanterv a pedagógus egyéni terveinek (ilyen a munkaterv vagy az óraterv) is alapját képezi, melyben a pedagógusok részletesen kidolgozva fogalmazzák meg a fejlesztendő képességek, készségek, tartalmakon keresztüli fejlesztését (Fóris-Ferenczi, 2007, 2008).

Az alaptanterv szerves részét képezik tehát a tantárgyi programok is. Mivel kutatásunkban az elemi iskolai tantervek áttekintését jelöltük meg célul, ezért a következökben ezek szerkezeti felépítésébe vezetjük be az olvasót. A tantárgyi programok megfogalmaznak 4-5 alapkompetenciát, melyek az adott diszciplínán belül elsajátítandó képességeket és készségeket tartalmazzák, egy meghatározott képzési szintre, osztályra (például IV. osztály). Ezeket hosszú távú követelményeknek is nevezhetjük, hiszen kialakításuk és fejlesztésük egy teljes tanévet felölel. Ezeket tovább bontja a program, rövid távú követelményekre, melyek a programban sajátos kompetenciákként jelennek meg. Ezeket rövidebb idő (egy óra/ hét/ hónap) alatt sajátítja el a tanuló a pedagógus segítségével. A sajátos kompetenciák mellé, a program tanulási tevékenységeket is rendel, melyek ezen kompetenciák kialakításában és fejlesztésében segítenek ${ }^{2}$. Ezeknek vizsgálata kitüntetett fontosságú kutatási fókuszonk szempontjából, ugyanis itt találhatunk utalásokat, példákat tanulási technikákra, stratégiákra, tevékenységekre is.

\footnotetext{
${ }^{1}$ Vass (2007) meghatározásában a kompetencia ügyességet és alkalmasságot fejez ki. Tanulmányunkban ezen értelmezés tükrében említjük a kompetencia fogalmát.

2 Például: alapkompetencia a "1. Beszédértés különböző kommunikációs helyzetekben", sajátos kompetencia "1.1. A mindennapi beszédhelyzetekben elhangzó funkcionális szövegek globális értése", tanulási tevékenység "szövegre való reagálás kérdések megválaszolásával” (Magyar nyelv és irodalom tanterv az anyanyelv oktatásához III. és IV. osztály; Programa şcolară pentru disciplina Limba şi liternatura maternă maghiară Clasele a III-a - a IV-a, 4).
} 
Mindezeken kívül a programok végén a módszertani útmutató mellett, a tartalmi javaslatokat találhatunk. Az alapkompetenciák a nagyobb képzési szakaszokban (általános iskola) ismétlődnek, a sajátos kompetenciák és a tanulási tevékenységek változnak (Fóris-Ferenczi-Birta-Székely, 2007; Kádár, 2016). Ennek értelmében elmondhatjuk, hogy mind a tanterv, így a tantárgyi programok is kompetenciaorientáltak, tehát a tanítás-tanulás folyamatának középpontjába a kompetenciák tanulói tevékenységek általi fejlesztését helyezik.

A tanterveken és tantárgyi programokon keresztül közvetített elvek, célok, melyek a különbözö tartalmak feldolgozása révén valósulnak meg, csak akkor érik el hatásukat - hatás alatt a teljes elsajátítást és eredményességet értjük -, ha ez az elsajátítás hatékony és egész életünkön keresztül „velünk marad”. Gaskó (2006) írja, hogy hatékony tanulási-tanítási folyamatról beszélünk akkor, mikor a pedagógus és a tanuló közötti interakciók mellett, a tanítás és a tanulás eredményeképp, a pedagógus által eltervezett célok megvalósulnak.

A hatékony tanítási-tanulási folyamat megvalósulásához, a hatékony tanulás biztosításához, hatékony oktatásra van szükség! Ehhez néhány alapelvnek kell teljesülnie, melyeket didaktikai alapelveknek nevezünk. Ezek olyan törvényszerüségek, melyek útmutatóként szolgálnak a hatékony folyamat létrejöttéhez. A pedagógus az alapelvek gyakorlatban való alkalmazásával, segíti a gyermek kezdeményezőkészségét, miközben önállóságra bíztatja, emellett pedig munkájának hatékonyságát is növeli. Az alapelvek a következőek: a tudatos és aktív elsajátítás alapelve, a szemléletesség (az érzéki és racionális megismerés) elve, az elmélet és gyakorlat összekapcsolásának elve, a rendszeresség és folytonosság elve, az ismeretek és készségek alapos elsajátításának elve, hozzáférhetőség és az egyéni foglalkoztatás elve, a visszacsatolás biztosításának elve (Barabási, 2007). Oroszlány (2002) néhány tanácsot fogalmaz meg, melyek szem előtt tartása (a pedagógus, a szülö és a tanuló részéről is) a hatékony tanuláshoz járul hozzá: a pedagógusnak kulcsfontosságú tudatosítania a tanulóban azt, hogy nem csak az otthoni tanulást kell tanulási tevékenységként értelmeznie, hanem az iskolában zajlót is; szorosan kapcsolva az előzőhöz, a házi és iskolai munkának össze kell függenie; a tanórára való felkészülés nem csak az ismeretek átismétlését jelenti, hanem a lelki felkészülést is magába foglalja; a pedagógus biztosítania kell minden tanuló számára a figyelni tudás lehetőségét (zavaró tényezők kizárása: zaj, sötétség); mivel a figyelem nehéz szellemi munka, ezért fontos olyan anyagot, illetve ezek bemutatására olyan módszereket, eszközöket kiválasztani, melyek könnyebbé és érdekesebbé teszik az elsajátítást; a tanító tudatosítsa a gyerekekben, hogy fontos az iskolában tanultak otthon való felfrissítése, rögzítése, gyakorlása, valamint ennek folyamán érdemes a megtanulandó tantárgyak sorrendjére és a tanulás közbeni pihenésre odafigyelni.

\section{Hatékony, eredményes tanulás és a tanulást segítő technikák}

Amennyiben a tanító munkája során a hatékony oktatás gyakorlatát képviseli, a tanuló megtanul hatékonyan, önmagáért, saját képességeihez igazítottan tanulni. Ezt önszabályzó tanulásnak nevezzük.

A tanulás olyan folyamat, mely egész életünket átszövi. Legyen szó akár szándékos tanulásról (mely irányított és erőfeszítést igényel), akár nem szándékos tanulásról (önkéntelenül megy végbe), e folyamat mindig jelen volt, van és lesz életünkben (Atkinson C. R., Hilgard E., Smith E. E., Nolen és Hoeksema S., Ferederickson L. B., Loftus R. G., 2005; Virág, 2013). Kovács (2007) Brunert é.n. vizsgálatát idézi, aki szerint a tanulás egy belső szerveződés, egy belső folyamat, mely három folyamatként jelenhet meg a tanuló viselkedésében: információ felvételként (az anyag elsajátítása), az információ transzferjeként (az anyag ismereteinek egy más területen való alkalmazása) és ezek értelmezéseként. Témánk feldolgozása során, a tanulás fogalma alatt a szerző által meghatározott értelmezést tartjuk szem előtt. 
A különböző pszichológiai nézetek ${ }^{3}$ más-más szempontból értelmezik a tanulás fogalmát. A behaviorista megközelítés szerint a tanulás inger-válasz kapcsolat eredménye. A behaviorizmusból fakad a neobehaviorizmus, amely hangsúlyozza, hogy a tanulásban és a viselkedés alakulásában szerepe van a bennünk zajló folyamatoknak, illetve a minket körülvevő, vagy ránk ható embereknek is (Virág, 2013). Nahalka (1997) a konstruktivizmus tanuláselméletét emeli ki, mely szerint a tanuló saját maga szervezi előzetes tudását az új információk értelmében, és önállóan építi, konstruálja tudását. Ha megfelelően rendezett és konstruált, akkor a tanulás sikeresen és eredményesen megy végbe. Ehhez viszont az is szükséges, hogy az új megtanulandó információ, összeegyeztethető legyen az előzetes tudásrendszerrel.

Kálmán (2006) a hatékony tanuláshoz szükséges feltételeket egy ház szerkezetének (lásd 1. ábra) alapján mutatja be. Eszerint, az alapot a külső feltételek jelentik, ezt követik a belső feltételek. Ezek megléte mellett a hatékony tanuláshoz elengedhetetlenek még a tanulási módszerek, technikák és a stratégiák.

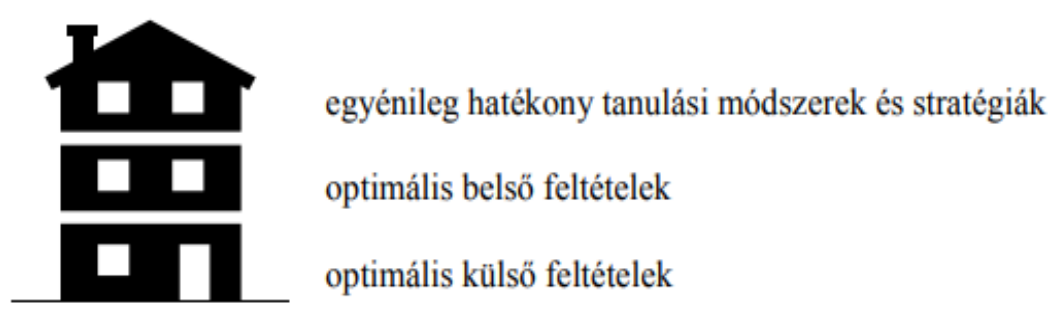

1. ábra - A hatékony tanuláshoz szükséges optimális külső és belső feltételek, valamint a tanulási módszerek és stratégiák rendszere (Kálmán, 2006, 42)

Gaskó (2006) írja, hogy a tanulás külső feltételeihez tartoznak a tanuláshoz szükséges eszközök (melyek az igényesség és a higiénia mentén a célok megvalósítását szolgálják); a hely (például íróasztal, asztal, melyeken elegendő helynek kell lennie ahhoz, hogy a tanuló kényelmesen elférjen); csendes környezetet (a zaj zavarja a koncentrációt, a figyelmet); a megfelelő fényviszonyok; kényelem, de a rend sem egy elhanyagolandó tényező. A belső feltételek a tanulóra vonatkoznak. Mind a pedagógusnak, mind a szülőnek célszerü figyelembe vennie a tanulás során a tanuló állapotát. Gondoljunk csak bele, hogy milyen nehézséget okoz betegen tanulni: nehéz koncentrálni, figyelni. Oroszlány (2002) szerint a tanuláshoz szükséges belső állapot legfontosabb eleme a pihent állapot. Fontos, hogy a tanuláshoz pihent állapotban fogjunk hozzá, hiszen a fáradtság csökkenti a teljesítőképességet, az aktív figyelem időtartamát, a koncentráció képességét, a munkabírást és a lényeg kiemelésének képességét is. Ezek elkerülése érdekében, ne csak otthon, hanem az iskolában is adjon a pedagógus lehetőséget a tanulóknak lazítani, pihenni.

A tanulási stratégiák meghatározásának széles körével találkozhatunk a szakirodalomban. Lukács (2006) szerint a tanulási stratégiák tanulási taktikákból épülnek fel, melyek olyan lépésnek tekinthetőek, melynek során a tanuló a tananyaggal kapcsolatosan fogalmaz meg kérdéseket, egyrészt ahhoz, hogy tovább haladhasson a tanulásban, másrészt ahhoz, hogy ezzel jobban megérthesse az adott részt. Ez a konstruálás, építkezés a konstruktivista szemléletet képviseli.

Balogh (1995) szerint a stratégiák tanulási technikákból tevőnek össze. A tanulók az egyes tanulási stratégiákat egyénre szabottan alkalmazhatják; egy tanuló használhat egy, de akár több stratégiát is. Nincs ez másképp a tanulási technikákkal sem, hiszen a technikák kombinációja más és más stratégiát eredményezhet. Szitó a következő tanulási technikákat említi (idézi Balogh 1995): olvasás (több féle képpen), ismétlés, jegyzet készítése, rajz készítése, áttekintés, beszélgetés, aláhúzás, kulcsfogalmak jegyzetelése/ meghatározása, ábra készítése és értelmezése, összefoglalás, fogalmi térkép készítése, stb.

\footnotetext{
${ }^{3}$ A pszichológiai nézőpont, ,a pszichológia egyes területeinek megközelítésénél alkalmazott szemlélet” (Atkinson és mtsai.,
} 2005, 749). 


\section{A kutatás bemutatása, hipotézisek, módszerek, eszközök}

Kutatásunk fö kérdése és témája az, hogy a nemzetközi felméréseken kimagaslóan jól teljesítő országok (mint Észtország és Svédország is) oktatást szabályzó dokumentumai milyen tanulási technikákat ajánlanak az elemi skolák pedagógusai számára, illetve mit közvetítenek a tanulásról mint folyamatról és az élethosszig tartó tanulás kérdéséről. Vizsgálatunk során - mind az imént említett északi országok, mind hazánk (Románia) tantervében, ahogyan a fentiekben is szóltunk róla -, az információk elsajátítását és szervezését segítő technikák feltárását céloztuk meg. Ezek alatt, azokat a technikákat értjük, melyek (ahogyan az általunk használt megnevezés is mutatja) segítenek a megtanulandó információk elsajátításában, illetve rendszerezésében. A technikák csoportjába a következőket soroltuk be: fogalmak közötti kapcsolatok kiemelése és rögzítése; gondolattérkép/ fürtábra készítése; jegyzet, vázlat készítése; kulcsfogalmak kiemelése, meghatározása; összefoglalás készítése; rajz készítése; lényegkielemlés (fogalmak aláhúzása). A dokumentumelemzés során, az előbbi technikák feltérképezését tartottuk elsődlegesnek, de emellett más tanulás segítő technikák tanulmányozását is lényeges feladatunkként jelöltük ki.

Neveléstudományi kutatásunkban tehát tanterveket, és ezek részeként tantárgyi programokat tekintettük át, dokumentum- és tartalomelemzés módszerével. Elöször hazánk, Románia oktatást szabályzó dokumentumát, majd az észt, a svéd terveket vettük szemügyre. Mindhárom terv esetében, ahogyan a fentiekben is említettük, a vizsgálatnál az előkészítő. - IV. osztályos terveket, a 6-10 éves korosztálynak szóló dokumentumokat tekintettük át. Hazánk tantervénél a vizsgálati szempont könnyen érvényesíthető volt, az észt és a svéd tervek tekintetében kisebb átfedéseket fedeztünk fel az osztályok valamint az életkor között. Az egyes dokumentumok esetében ezért ez a következő formában valósult meg:

- hazai (Románia) tervek: előkészítő, I., II., III., IV. osztály (6-10 éves gyerekek)

- észt tervek: „First Stage of Study” (I., II. és III. osztályos tanulók, 7-9 éves gyerekek), „Second Stage of Study" (IV., V., VI. osztályos, 10-12 éves diákok)

- svéd tervek: előkészítő („,school-age educare”, 6 év), I., II., III. („years 1-3”, 7-9 év), IV. osztály (,years 4", 10 év)

Minden terv esetében az tartalom- és dokumentumelemzési szempontok a következőek voltak:

- Milyen tanuláselméletet közvetítenek?

- Mit közvetítenek a tanulásról, a tanulás folyamatáról?

- Mit közvetítenek az élethosszig tartó tanulás folyamatáról?

- Milyen az információk elsajátítását és szervezését segítő tanulási technikákat ajánlanak? Ezen vizsgálati szempont esetében, azokat a technikákat kerestük, amelyeket a fentiekben megjelöltünk. Emellett kíváncsiak voltunk arra, hogy milyen tevékenységeknél, tartalmaknál ajánlják ezeket a tantárgyi programok? Milyen más technikákat találhatunk még?

A vizsgálat hipotézisünk valóságértékének bizonyítását vagy cáfolását szolgálja, mely szerint feltételezzük, hogy a nemzetközi felméréseken eredményesen teljesítő országok (Észtország, Svédország) tanterveiben és tantárgyi programjaiban, nagyobb számban fordulnak elő ajánlott tanulási technikák mint a hazai, romániai alaptantervben és tantárgyi programjaiban.

Vizsgálatuk szükségességét és értékét a következőkben látjuk: mind a pedagógusok, mind a szülök számára, olyan tényekkel, illetve hasznos információkkal tudunk szolgálni, melyek a pedagógusok esetében mindennapi munkájukat, a szülök esetében pedig tanuló gyerekeik iskolai kötelezettségeit tudják segíteni. Tehát az oktató-nevelő tevékenységének eredményességéhez járulhat hozzá. Kutatásunk így tájékoztató jelleggel bír, emellett a tantervfejlesztéshez is hozzájárulhat, a különbözö nemzetközi programok bizonyos részeinek integrálásával. 


\section{Eredményeink: Románia, Észtország és Svédország tanterve és tanulási technikái}

Hazánk, Románia tantervének, így tantárgyi programjainak áttekintése után is a következőket találtuk.

- A romániai tanterv (Curriculumul Naţional, 3) „a tanulót állítja a középpontba”, és a hangsúlyt a tanításról a tanulásra irányítja. Fő irányaiként említi a „tanulás adaptációját a diákok fejlődéséhez és érdeklődéséhez". A tanítási-tanulási folyamatot a kulcskompetenciákra- és azok fejlesztésére alapozza, mely a készségek, képességek és jártasságokon túl, a gyermek személyiségfejlődéséhez a maga teljességében is hozzájárul. A folyamatot egy aktív, interaktív és felfedező procedúrának tekinti, melyben a tanulás felfedezésre és problémamegoldásra alapoz. Ugyanakkor azt is megjelöli, hogy ezen folyamat túllép az ismeretek közlésén (a pedagógus által) és elsajátításán (a tanuló részéről), mivel a pedagógus ftámogató, facilitáló tevékenységén, valamint a tanuló tudásának konstrukcióján alapszik. Ezen tényeket számba véve, összegezve elmondhatjuk, hogy a vizsgált tanterv a konstruktivista tanuláselméletet közvetíti, és arra alapoz.

- A tantervben az élethosszig tartó tanulás folyamatával kapcsolatosan hivatkozást találhatunk az Európai Parlament és Tanács 2006/962/EC cikkelyére, mely kiemeli az élethosszig tartó tanulás folyamatának szükségességét (Curriculumul Național, 13, 42-43).

- A tantárgyi programok áttekintése után elmondhatjuk, hogy a technikák szép számban gazdagítják a tantárgyi programokat, legyen szó akár az információk elsajátítását és szervezését segítő technikákról, akár a más tanulást segítőkröl. Az elöbbieket tekintve, összesen 17 technikát találtunk, például: grafikonok, táblázat készítése, rajz, visszamesélés, vázlat és pókhálóábra készítése, lényegkiemelés, összehasonlítás, ismeretlen kifejezések kontextusból való kikövetkeztetése, ismétlés, hangos/ néma olvasás. A más tanulást segítő technikákból 51 darabot számláltunk, például: válaszok megfogalmazása kérdésekre. Az eredményeket méginkább részletezve a következőket fogalmazhatjuk meg: az információk elsajátitását és szervezését segitő technikákat illetően a nyelvek célzó (Magyar nyelv és irodalom, Román nyelvi kommunikáció) tantárgyak esetében találtuk a legtöbb technikát, rendre 5 és 3 . Az osztályok szerinti eloszlást tekintve pedig a IV. osztályos tantárgyi programokban fordult elö a legtöbb technika, szám szerint 5. Ami a más tanulást segitö technikákat illeti, a tantárgyi eloszlást tekintve szintén a nyelvet célzó (Magyar nyelv és irodalom, Román nyelv és irodalom/Román nyelvi kommunikáció) programoknál fordult elő a legtöbb, rendre 8, 16 és 13 . Az osztályok szerinti eloszlást tekintve, a III. osztályosoknak szánt programokban találkozhatunk a legtöbb más tanulást segítő technikával, szám szerint 24-gyel.

Az észt tantervet, és részeként a tantágyi programokat átvizsgálva az alábbiakat találtuk:

- Az észt kisiskolásoknak szóló tanterv, (angolul) „National curricula for basic schools”, azaz Nemzeti Curriculum általános iskoláknak, 2014 óta van máig is érvényben. A tervben a tanulás fogalmáról a harmadik, „A tanulás fogalma és a tanulási környezet” (in National curricula for basic schools, 2014, 5-6), fejezetben olvashatunk. Az említett dokumentumból egyértelmüen kitünik, hogy a tanulást mint a gyermek, vagy gyerekek csoportjának kimeneti eredményeiként, a viselkedésrendszerükben és képességeikben végbemenő változásokként értelmezi. Pontosabban ez azt jelenti, hogy a tanulás olyan tudás, képességek, tapasztalatok, értékek és attitüdök elsajátítása, melyek szükségesek a mindennapi élethez. A tanulás pszichológiai alapjai a pszichikai, mentális és a környezetben szerzett tapasztalatok kombinációjában rejlik. Ahogyan a gyerek tapasztalatokat szerez, elkezd sikerorientáltan viselkedni. Az iskola tanulási környezetének támogatnia kell a rendszerezett és sikerorientált tanulást, illetve azt, hogy az oktatási tevékenység a tanterv alapján menjen végbe, és vegye figyelembe az otthoni és közvetlen környezetet. A tanulónak az elsajátított ismereteket tudnia kell alkalmazni, be kell tudnia építeni új helyzetekbe, tudnia kell problémák megoldásnál, döntéshozatalnál, helyes érvek alátámasztásánál és érveinek evidenciájának bizonyításánál, valamint jövőbeli tanulmányaiban alkalmazni. (A tudáskonstrukció értelmében elmondhatjuk, hogy az észt tanterv a románhoz hasonlóan a konstruktív tanuláselméletet közvetíti.) A tanulás egy élethosszig tartó folyamat, melyhez szükséges az alapfokú oktatás során a tanulási képességek és a munkabeli szokásos alakítása. 
- Áttekintve a szillabuszokat azt a következtetést vontuk le, hogy a tanulási technikák száma nem kimagasló a programokban, hiszen míg az információk elsajátitását segitö technikák esetében szám szerint 6 technikát (szavak meghatározása, vázlat és térkép készítése, ismétlés, tartalmak összekapcsolása, jegyzetkészítés) találtunk, addig a más tanulást segitö technikák esetében is csupán 20 technikát (például: kérdéseket fogalmaznak meg, válaszolni tudnak kérdésekre, információkeresés, összehasonlítás) fedeztünk fel. Legnagyobb számban a nyelveket célzó (anyanyelv és irodalom, idegen nyelv) szillabuszokban találhatunk az információk elsajátítását és szervezését segítő technikákat, valamint más tanulást segítő technikákat is. A korosztályt tekintve külön részletezni nem tudjuk a technikák előfordulásának számát, mivel a vizsgált koroszály esetében az elérendő, tanulandó készségek és képességek a teljes szakaszra vonatkoznak. Tehát nem találhatjuk meg külön-külön lebontva, hogy a 8, 9, 10 éves gyerekek az egyes tanulási technikák segítségével milyen készséget, képességet kell esajátítsanak.

Svédország tantervét, és részeként a tantágyi programokat átvizsgálva az alábbiakat találtuk:

- A svéd, (angolul) Curriculum for the compulsory school, preschool class and the recreation centre, 2011, azaz Tanterv a kötelező iskola, előkészítő és rekreációs központ számára, 2011 (2018-ban felülvizsgálva: a változások értelmében a tanterv új címe „Curriculum for the compulsory school, preschool class and school-age educare REVISED 2018”, azaz „Tanterv a kötelező iskola, az óvoda és az iskoláskorúak oktatása számára 2018-ban felülvizsgálva" lett.) tanterv leglényegesebb közvetített céljai: támogatja minden gyerek fejlődését és tanulását, és az élethosszig tartó tanulás vágyát is. »Az ekvivalens oktatás« címú alfejezetben olvashatjuk továbbá, hogy az oktatást minden tanuló körülményeinek és szükségleteinek megfelelően kell megszervezni. Melynek támogatnia kell a tanulók jövőbeli tanulását [...]. »Az iskola feladatai« alfejezet kiemeli, hogy az iskola feladata a tanulás támogatása az egyén tudás- és értékelsajátítási tevékenységének ösztönzésével, fejlesztésével. Az iskola felhatalmazással rendelkezik az alapvető értékek közvetítésére és beágyazására, valamint a tanulók tanulásának előmozdítására, annak érdekében, hogy az felkészítse őket a társadalomba való beilleszkedésre, munkára, az életre" (Curriculum for the compulsory school, preschool class and school-age educare, 2018, 5-7). A 2.6-os „Az iskola és a környező világ” alfejezetben hangsúlyozott a célok tekintetében, hogy ,az iskola célja, minden gyermek alapos tájékoztatása arra vaonatkozóan, hogy milyen továbbtanulási lehetőségei vannak Svédországban és más országokban" (Curriculum for the compulsory school, preschool class and school-age educare, 2018, 15).

- A tervben konkrét utalást nem találunk arra, hogy mely tanuláselméletet képviseli a terv. Figyelembe véve, hogy a terv az alábbiakat emeli ki: ,aktív tanulás; koherens szemléletmód kialakítása; a gyerekek használják tudásukat, tudományos, technikai, szociál-tudományos, humanisztikus és esztétikai területeken, a továbbtanulásban, a társas és mindennapi életben; oldjanak meg problémákat; vigyék át ötleteiket cselekvésbe kreatív módon; egyenek képesek felhasználni az újonnan szerzett ismereteket" (Curriculum for the compulsory school, preschool class and school-age educare, 2018, 7-11), elmondhatjuk, hogy a svéd curriculum is a konstruktivista tanuláselmélet jegyeit közvetíti.

- A 2.2.-es „Tudás” alfejezet azt mutatja be, hogy az általános iskola befejezésével a tanulóknak mely ismeretekkel kell rendelkeznie a tanulmányi szakaszból kilépve. Ezek között szerepel az, hogy „,a gyermek tud önállóan és másokkal együttdolgozva tanulni, felfedezni és munkálkodni, illetve magabiztosnak érzi magát saját képességeiben”. Ugyancsak ebben a részben kerülnek nyomatékosításra a tanító feladatai is, melyek között szerepel, hogy „erősítse meg a tanulók tanulási vágyát, valamint a tanulók bizalmát a saját képességeikben" (Curriculum for the compulsory school, preschool class and school-age educare, 2018, 12).

- Az áttekintés után elmondhatjuk, hogy konkrét tanulási technikák nincsenek a svéd terv szillabuszaiban. Az olvasás gyakorlatával kapcsolatosan találtunk olyan stratégiákra, az olvasást segítő módszerekre utalást (például "olvasási stratégiák szavak és mondatok értéséhez és értelmezéséhez egyszerü szövegekben" [Curriculum for the compulsory school, preschool class and school-age educare, 2018, 114.]), melyek az információk elsajátításához és szervezéséhez járulhatnak, járulnak hozzá. Viszont, ezek sem konkrétan pontosítottak. A szillabuszok 
tartalmakat jelölnek meg (mely a szillabusz müfaji sajátosságaiból, jegyeiből fakad), ezek között pedig az, hogy milyen technikákkal, módszerekkel ajánlatos elsajátítani őket, nem jelenik meg. Ennek értelmében hasonló következtetéseket tudunk megfogalmazni, mint ahogyan azt az észt szillabuszok esetében is tettük: a pedagógus teljes körü szabadsága és feladata az, hogy eldöntse, hogy a megjelölt tartalmakat, milyen tanulási technikákkal és módszerekkel dolgoztatja fel és sajátíttatja el a tanulókkal.

Összegzésképpen elmondhatjuk, hogy az általunk vizsgált tervek a tanulót helyezik a tanulás-tanítás folyamatának középpontjába, a konstruktivista tanuláselméletet képviselik, valamint támogatja az élethosszig tartó tanulás folyamatát. A romániai tantárgyi programokban kiemelkedő mind az információk elsajátítását, mind a más tanulást segítő technikák száma. Az észt programokban, habár az előbbihez képest előfordulnak technikák, de sokkal kisebb számban. Ezzel ellentétben a svéd szillabuszokban egyáltalán nem találunk sem az információk elsajátítását segítő, sem más tanulást segítő technikákat.

A vizsgált országok tanterveinek tanulási technika javaslat-megjelenítésével kapcsolatosan következtetésként kiemeljük tehát azt, hogy a romániai tantárgyi programokban fordul elő a legtöbb általunk vizsgált technika (az információk elsajátítását és szervezését segítő technikákat, és a más tanulást segítő technikákat tekintve is). Állításunkat az alábbi ábrával (lásd 2. ábra) támasztjuk alá. Tehát feltételezésünk, mely szerint összefüggésben van egy ország (jelen esetben Észtország és Svédország) oktatási rendszerének eredményessége és a tanterv tanulási technika-ajánlatának gazdagsága között nem igazolódott be.

\section{Az információk elsajátítását és szervezését segítő, valamint a más tanulást segítő technikák száma az észt, svéd és hazai, romániai tantárgyi programokban}

— Az információk elsajátítását és szervezését segítő technikák অás tanulást segítő technikák

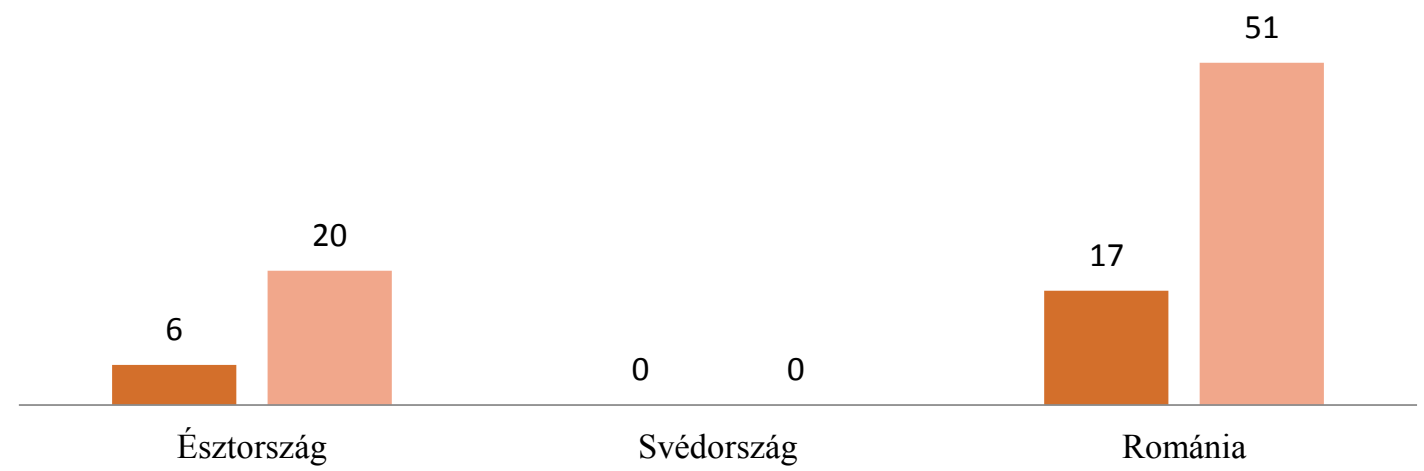

2. ábra - Az információk elsajátítását és szervezését segítő, valamint a más tanulást segítő technikák száma az észt, svéd és hazai, romániai tantárgyi programokban

\section{Összegzés}

A tantervek vizsgálata után elmondhatjuk, hogy mind az észt és a svéd, mind a romániai tanterv támogatja az élethosszig tartó tanulást. Kiemelik az Európai Parlament és Tanács 2006/962/EC cikkelyében szereplő nyolc kompetencia közül a tanulás tanulásának kompetenciáját, mely a jövőbeli tanulást, az élethosszig tartó tanulás folyamatát támogatja. Emellett szintén közös pont a tervekben, hogy a konstruktív tanuláselméletet közvetítik. Vagyis, a tanulást úgy tekintik mint központi tevékenységet, melyben a tanuló saját maga építi fel, konstruálja tudását, illetve szervezi azt, az új valamint a már elsajátított információk tekintetében. Mind a romániai, mind az észt, mind a svéd curriculum fontos szerepet tulajdonít a tanulási környezetnek. Kiemelik, hogy a tanulási környezet jelentősen befolyásolja a tanulók tanulásának eredményességét, így annak olyan jegyekkel kell bírnia, mely a diákok fejlődését, igényeit és életkori sajátosságainak megfelelő tevékenységeit támogatja. A 
tantervek és tantárgyi programok/ szillabuszok teljes körü áttekintése után, következtetésképpen elmondhatjuk, hogy a nemzetközi felméréseken eredményesen teljesítő országok tantárgyi programjaiban/ szillabuszaiban nem fordulnak elő nagyobb számban az információk elsajátítását és szervezését segítő technikák, mint a hazai, romániai programokban. Sőt, a technikák számát illetően ki kell emelnünk, hogy a romániai tantárgyi programok gazdagabbak a vizsgált technikákat tekintve. Tehát hipotézisünk mi szerint, a nemzetközi felméréseken eredményesen teljesítő országok (Észtország, Svédország) tanterveiben és tantárgyi programjaiban, nagyobb számban fordulnak elő ajánlott tanulási technikák mint a hazai, romániai alaptantervben és tantárgyi programjaiban, nem igazolódott be. Így kijelenthetjük, hogy nincs összefüggés az általunk vizsgált országok tanterveiben, tantárgyi programjaiban/ szillabuszaiban megjelenő tanulási technikák, és az adott ország nemzetközi felméréseken elért teljesítményei (a tanulás folyamatát tekintve, eredményessége) között. Feltételezésünk szerint a vizsgált országok szillabuszaiban azért találkoztunk kevés az információk elsajátítását és szervezését segítő technikával, mert a pedagógus szakmai kompetenciája alapján, szabadon dönt, hogy mely technikákkal alkalmazza a tanulási-tanítási tevékenység során.

A kutatás továbbfejlesztési lehetőségeként említhetjük a kiterjesztést, olyan szempontból, hogy további, a nemzetközi felméréseken jól teljesítő országok tanterveit is érdekes és érdemes lenne áttekinteni, mint például Finnország, és az utóbbi években, az eredményeket tekintve emelkedő tendenciát mutató (Szingapúr, Hongkong, Tajvan és Japán) országok tanterveit is célszerü lenne átvizsgálni. Ezek tekintetében kérdéses a tervek elérhetősége, valamint a nyelvi hozzáférhetőség. A kutatásnak egy másik folytatási szálaként, a tanulók által alkalmazott tanulási technikákra is célravezető lehetne rákérdezni.

\section{Irodalomjegyzék}

Atkinson C. R., Hilgard E., Smith E. E., Nolen-Hoeksema S., Ferederickson L. B., Loftus R. G. (2005): Pszichológia. Harmadik átdolgozott kiadás. Osiris Kiadó, Budapest

Balogh Z. (1995): Tanulási stratégiák és stílusok, a fejlesztés pszichológiai alapjai. KLTE Kiadói Bizottság, Debrecen, URL: http://www.mateh.hu/tehetsegkonyvtar/Dr_Balogh_konyvek/Tanulasi_ strategiak_es_stilusok.pdf (2020.03.20.)

Barabási T. (2007): Az oktatási rendszer és az oktatás folyamata. In: Fóris-Ferenczi R., Birta-Székely N.: Pedagógiai kézikönyv. Az oktatás pedagógiaelméleti alapjai. Ábel Kiadó, Kolozsvár, 97-104.

Curriculum for the compulsory school, preschool class and school-age educare (2018), Skloverket, Stockholm, Sweden, URL: https://www.skolverket.se/sitevision/proxy/publikationer/svid12_5dfee 44715d35a5cdfa2899/55935574/wtpub/ws/skolbok/wpubext/trycksak/Blob/pdf3984.pdf?k=3984 (2020.03.20.)

Curriculumul Național (2015), Institutul de Științe ale Educației, URL: http://www.ise.ro/wpcontent/uploads/2015/12/Document-politici-curriculum_final_23decembrie.pdf (2020.03.20.)

Fóris-Ferenczi R. (2007): A tanterv elméleti és gyakorlati problémaköre. Tantervi reform a romániai oktatásban. In: Fóris-Ferenczi R., Birta-Székely N.: Pedagógiai kézikönyv. Az oktatás pedagógiaelméleti alapjai. Ábel Kiadó, Kolozsvár, 203-263.

Fóris-Ferenczi R. (2008): A tervezéstől az értékelésig. Ábel Kiadó, Kolozsvár

Gaskó K. (2006): A tanulás pszichológiai értelmezése. In (szerk.) Nahalka I. (2006): Hatékony tanulás. A gyakorlati pedagógia néhány alapkérdése. Bölcsész Konzorcium, Budapest, http://mek.niif.hu/05400/05446/05446.pdf (2020.03.20.)

Kádár E. (2016): A magyar nyelv tantárgy tartalma és oktatása a romániai oktatás-szabályozási keretben. Institutul pentru studierea problemerol minorităților naționale, Kolozsvár

Kálmán O. (2006): A tanulásról és magunkról mint tanulóról alkotott elképzelések. In (szerk.) Nahalka I. (2006): Hatékony tanulás. A gyakorlati pedagógia néhány alapkérdése. Bölcsész Konzorcium, Budapest, URL: http://mek.niif.hu/05400/05446/05446.pdf (2020.03.20.) 
Kovács Z. (2007): Neveléstudományi kérdések. Kolozsvári Egyetemi Kiadó, Kolozsvár

Lukács I. (2006): Tanulási stratégia és tanulási stílus. In (szerk.) Nahalka I. (2006): Hatékony tanulás. A gyakorlati pedagógia néhány alapkérdése. Bölcsész Konzorcium, Budapest, URL: http://mek.niif.hu/05400/05446/05446.pdf (2020.03.20.)

MAGYAR NYELV ÉS IRODALOM Tanterv az anyanyelv oktatásához III. és IV. osztály; Programa şcolară pentru disciplina Limba şi liternatura maghiară maternă Clasele a III-a - a IV-a (2014), Ministrul Educației Naționale, București, http://programe.ise.ro/Portals/1/Curriculum/2014-12/03Limba\%20si\%20literatura\%20romana $\% 20 \mathrm{pt} \% 20$ scolile $\% 20$ si $\% 20$ sectile $\% 20 \mathrm{in} \% 20 \mathrm{lb} \% 20 \% 20 \mathrm{maghi}$ ara_clasele\%20a\%20III-a\%20-\%20a\%20IV-a.pdf (2020.03.20.)

Nahalka I. (1997): Konstruktív pedagógia - egy új paradigma a láthatáron (I.). Iskolakultúra, 2. URL: http://epa.oszk.hu/00000/00011/00122/pdf/1997-2.pdf (2020.03.20.)

National curriculum for basic schools (2014), Government Of The Republic, Tallinn, Toompea, URL: https://www.hm.ee/sites/default/files/est_basic_school_nat_cur_2014_general_part_1.pdf (2020.03.20.)

Oroszlány P. (2002): Könyv a tanulásról. Tanulási képességet fejlsztö tréning 12-16 éveseknek. Nyolcadik, változatlan kiadás. AKG Kiadó, Budapest

PIRLS és TIMSS tájékoztató 2011. In Oktatási Hivatal, Budapest, https://www.oktatas.hu/ pub_bin/dload/kozoktatas/nemzetkozi_meresek/pirls/PIRLS_TIMSS_2011_tajekoztato.pdf (2020.03.20.)

PISA 2015 Összefoglaló jelentés. In Oktatási Hivatal, Budapest, https://www.oktatas.hu/pub_bin/ dload/kozoktatas/nemzetkozi_meresek/pisa/PISA2015_osszefoglalo_jelentes.pdf (2020.03.20.)

Szivák J. (2003): Az oktatás célrendszere. In (szerk.) Falus I.: Didaktika. Hatodik átdolgozott kiadás. Nemzeti Tankönyvkiadó Rt., Budapest, 255-272.

Vass V. (2007): Az oktatás tartalma mint fejlesztési eszköz. Új Pedagógiai Szemle, június, http://epa.oszk.hu/00000/00035/00114/2007-06-ta-Vass-Oktatas.html (2020.03.20.)

Virág I. (2013): Tanuláselméletek és tanitási-tanulási stratégiák. Eszterházy Károly Főiskola, Eger, URL: https://mek.oszk.hu/14900/14953/ (2020.03.20.)

\section{Szerzők}

Bardocz Orsolya, végzős mesteris hallgató, Babes-Bolyai Tudományegyetem, Székelyudvarhelyi Kihelyezett Tagozat, Székelyudvarhely (Románia) E-mail: orsolyabardocz@ gmail.com

Barabási Tünde, PhD, Babes-Bolyai Tudományegyetem, Székelyudvarhelyi Kihelyezett Tagozat, Székelyudvarhely (Románia). E-mail: tunde.barabasi@gmail.com 